\title{
Potential for utilization of wood ash on coastal arenosols with limited buffer capacity in KwaZulu-Natal and its effect on eucalypt stand nutrition and growth
}

\author{
Gerhardus Petrus Scheepers, \\ Ben du Toit
}

\section{Introduction}

The processing and manufacturing of timber and timber-related products is energy intensive. As an approach to reduce the high costs of energy, commercial and privately owned companies have turned to the combustion of by-products from the manufacturing chain to generate heat and power. Sawmills and paper mills make use of foliage, branch wood, stem wood and bark biomass for energy generation (Gavrilescu 2008). The combustion of these materials is favored due to the relatively low wood ash generation of the materials (Pit-

\begin{abstract}
A field trial was established to test the effects of various wood ash and fertilizer application rates on the nutrition and early growth of a clonal Eucalyptus grandis $\times$ urophylla stand near Richards Bay, KwaZulu-Natal province, South Africa. The trial consisted of wood ash treatments of $0,0.3,0.6$ and $1.2 \mathrm{t} \mathrm{ha}^{-1}$, combined with fertilizer treatments of no fertilizer (control), $150 \mathrm{~g}^{\text {tree }}{ }^{-1}$ of conventional ammonium sulphate fertilizer or $320 \mathrm{~g} \mathrm{tree}^{-1}$ of controlled release fertilizer mixture containing $\mathrm{N}, \mathrm{P}$ and a balanced suite of several plant nutrients. The experiment was conducted on a young sandy soil of aeolian origin with a very low buffer capacity. Ash application rates were chosen after a pilot study was conducted to test the effect of $\mathrm{CaCO}_{3}$ on the soil reaction. At 4 and $\mathbf{8}$ months after treatment, soil heavy metal concentrations for cadmium (Cd), mercury $(\mathrm{Hg})$, chromium $(\mathrm{Cr})$ and lead $(\mathrm{Pb})$ levels were substantially lower than toxic levels. Foliar heavy metal concentrations (for the same elements) were less than $1 \mathrm{mg} \mathrm{kg}^{-1}$ at both time intervals. The wood ash induced a temporary liming effect up to 8 months after application. Foliar nutrient assessments revealed sub-optimal nutrient concentrations for phosphorous (P), potassium $(\mathrm{K})$ and zinc $(\mathrm{Zn})$ at 4 months and $\mathrm{K}$ at 8 months of age. The positive growth responses (expressed as a biomass index) at 8 months, ranged between $13 \%$ and $683 \%$ relative to the untreated control. At 21 months, the growth response to ash and fertilizer combinations ranged from $-0.5 \%$ to $50 \%$ relative to the control. This research demonstrated that $1.2 \mathrm{t} \mathrm{ha}^{-1}$ of wood ash can safely be disposed of on a typical, poorly buffered Zululand coastal sand with little environmental risk and minimal growth suppression, provided that it is balanced with an appropriate NPS plus trace element fertilizer mixture.
\end{abstract}

Keywords: Wood Ash, Eucalyptus grandis $\times$ urophylla, Stand Nutrition, Entisol, Heavy Metals, Fertilizer man 2006, James et al. 2012). In South Africa, wood ash is generally stored on landfills. Increasing storage costs and tightening environmental laws have made it essential for companies to investigate alternative disposal methods. Wood ash contains substantial quantities of nutrients and has the potential to partly substitute nutrients removed per rotation from tree harvesting, with the exception of $\mathrm{N}$ (Lévai et al. 2009, Pitman 2006). In addition, wood ash induces a liming effect once introduced to a soil and is attributed to the substantial quantities of carbonates, hydroxides, ox- $\square$ Department of Forest and Wood Science, Stellenbosch University, Private Bag X1, Matieland 7602 (South Africa)

@ Ben du Toit (ben@sun.ac.za)

Received: Jun 20, 2016 - Accepted: Oct 04, 2016

Citation: Scheepers GP, du Toit B (2017). Potential for utilization of wood ash on coastal arenosols with limited buffer capacity in KwaZulu-Natal and its effect on eucalypt stand nutrition and growth. iForest 10: 180-188. - doi: 10.3832/ifor2146-009 [online 2016-11-19]

Communicated by: Claudia Cocozza ides and other calcium containing minerals in the ash (Mandre 2006). Wood ash has the potential to increase the productivity and growth of natural and plantation forests. Its application has been tested extensively on forest soils with low $\mathrm{pH}$ and moderate to high buffer capacities, but very limited research has been done on sandy soils with low buffer capacity and $\mathrm{pH}>5$ (Guerrini et al. 2000, Demeyer et al. 2001, Mandre et al. 2004, Saarsalmi et al. 2012, Scheepers 2014, Scheepers \& du Toit 2016). In step with the international legislation, the South African National Environmental Management: Waste Act (South Africa Act No. 59 of 2008) classifies wood ash as a Level 2, i.e. Major Waste; this is due to the occurrence of heavy metals such as $\mathrm{Cd}, \mathrm{Pb}$, arsenic (As), selenium (Se), nickel $(\mathrm{Ni})$ and Cr (Pitman 2006, Bird \& Talberth 2008). However, pure wood ash contains lower heavy metal concentrations relative to coal and boiler fired ash, and is better suited to land applications (Elliott \& Mahmood 2006, Pitman 2006, Bird \& Talberth 2008). The potential risks of heavy metal contamination, water contamination, immobilisation and volatilisation of essential macro and 
Tab. 1 - Basic soil chemical properties of the soil at the experimental site. (SE): standard error.

\begin{tabular}{|c|c|c|c|c|c|c|c|}
\hline \multirow{2}{*}{ Parameter } & \multicolumn{5}{|c|}{ Sample } & \multirow{2}{*}{ Mean } & \multirow{2}{*}{ SE } \\
\hline & A1 & A2 & A3 & A4 & A5 & & \\
\hline Sample Density $\left(\mathrm{kg} \mathrm{m}^{-3}\right)$ & 1470 & 1480 & 1480 & 1500 & 1510 & 1488 & 7.35 \\
\hline Clay (\%) & 7 & 6 & 5 & 6 & 7 & 6.2 & 0.37 \\
\hline $\mathrm{C}(\%)$ & 0.6 & $<0.5$ & $<0.5$ & $<0.5$ & $<0.5$ & - & - \\
\hline$N(\%)$ & $<0.05$ & $<0.05$ & $<0.05$ & $<0.05$ & $<0.05$ & - & - \\
\hline Bray II P (mg kg $\left.{ }^{-1}\right)$ & 1.36 & 1.35 & 1.35 & 1.33 & 1.32 & 1.34 & 0.01 \\
\hline $\mathrm{K}\left(\mathrm{cmol}_{\mathrm{c}} \mathrm{kg}^{-1}\right)$ & 0.03 & 0.06 & 0.02 & 0.03 & 0.02 & 0.03 & 0.01 \\
\hline $\mathrm{Ca}\left(\mathrm{cmol}_{c} \mathrm{~kg}^{-1}\right)$ & 1.69 & 2.11 & 1.35 & 1.56 & 1.01 & 1.54 & 0.18 \\
\hline $\mathrm{Mg}\left(\mathrm{cmol}_{c} \mathrm{~kg}^{-1}\right)$ & 0.19 & 0.23 & 0.15 & 0.18 & 0.18 & 0.19 & 0.01 \\
\hline Total Base Cations $\left(\mathrm{cmol}_{\mathrm{c}} \mathrm{kg}^{-1}\right)$ & 1.92 & 2.40 & 1.52 & 1.77 & 1.22 & 1.78 & 0.20 \\
\hline $\mathrm{Zn}\left(\mathrm{mg} \mathrm{kg}^{-1}\right)$ & 0.20 & 0.14 & 0.47 & 0.33 & 0.20 & 0.29 & 0.06 \\
\hline $\mathrm{Mn}\left(\mathrm{mg} \mathrm{kg}^{-1}\right)$ & 2.72 & 4.05 & 2.70 & 4.00 & 3.31 & 3.36 & 0.30 \\
\hline $\mathrm{Cu}\left(\mathrm{mg} \mathrm{kg}^{-1}\right)$ & 0.34 & 0.41 & 0.47 & 0.33 & 0.26 & 0.36 & 0.04 \\
\hline Acid saturation (\%) & 5 & 3 & 5 & 4 & 9 & 5.20 & 1.02 \\
\hline $\mathrm{pH}(\mathrm{KCl})$ & 5.76 & 6.16 & 5.55 & 5.46 & 4.62 & 5.51 & 0.25 \\
\hline Buffer capacity ${ }^{\#}$ (mg kg ${ }^{-1}$ per pH unit) & 74.07 & - & 48.78 & 55.56 & 14.99 & 48.35 & 12.34 \\
\hline Lime requirement, $0.3 \mathrm{~m}$ deep $\left(\mathrm{t} \mathrm{ha}{ }^{-1}\right)$ & 326.65 & - & 216.58 & 250.02 & 215.83 & 215.29 & 54.26 \\
\hline
\end{tabular}

micro nutrients and possible nutrient imbalances is greatly influenced by site conditions, soil properties, wood ash application rate and abiotic factors (Demeyer et al. 2001, Pitman 2006). It is evident from the reviewed literature that the effects of wood ash applications on stand nutrition and development tends to be highly sitespecific (Scheepers \& du Toit 2016). The Zululand coastal plain of South Africa has more than 50000 ha of industrial plantation forests and many wood-burning processing plants. The coastal plain soils are sensitive to poor management practices, as demonstrated by the nutritional disorders that have been experienced with soils that have low organic matter in the topsoil (du Toit \& Oscroft 2003), as well as old agricultural lands that had been intensively tilled and burnt (du Toit et al. 2001). We explored the feasibility of disposing pure wood ash in an area where it is produced in large quantities on a plantation soil as an alternative disposal method. More specifically, this paper examined the changes in Eucalyptus grandis $\times$ urophylla stand

Tab. 2 - Application rates of nutrient elements used in the $F_{C R F}$ (controlled release) prescription blend and $\mathrm{F}_{\mathrm{CV}}$ (conventional) fertilizer.

\begin{tabular}{|c|c|c|}
\hline \multirow{2}{*}{ Element } & \multicolumn{2}{|c|}{ Treatment } \\
\hline & $F_{\mathrm{CRF}}$ & $\mathbf{F}_{\mathrm{cV}}$ \\
\hline $\mathrm{N}\left(\mathrm{g} \mathrm{tree}^{-1}\right)$ & 80 & 40 \\
\hline $\mathrm{P}\left(\mathrm{g}\right.$ tree $\left.^{-1}\right)$ & 20 & - \\
\hline $\mathrm{K}\left(\mathrm{g}\right.$ tree $\left.^{-1}\right)$ & 0 & - \\
\hline $\mathrm{Ca}\left(\mathrm{g} \mathrm{tree}^{-1}\right)$ & 10 & - \\
\hline $\mathrm{Mg}\left(\mathrm{g}\right.$ tree $\left.^{-1}\right)$ & 1 & - \\
\hline $\mathrm{S}\left(\mathrm{g}\right.$ tree $\left.{ }^{-1}\right)$ & 12 & 19 \\
\hline $\mathrm{B}\left(\mathrm{mg}\right.$ tree $\left.^{-1}\right)$ & 0 & - \\
\hline $\mathrm{Cu}\left(\mathrm{mg}\right.$ tree $\left.^{-1}\right)$ & 90 & - \\
\hline Fe $\left(m g\right.$ tree $\left.{ }^{-1}\right)$ & 128 & - \\
\hline$M n\left(m g\right.$ tree $\left.{ }^{-1}\right)$ & 96 & - \\
\hline Mo (mg tree $\left.{ }^{-1}\right)$ & 0 & - \\
\hline Zn $\left(m g\right.$ tree $\left.{ }^{-1}\right)$ & 1152 & - \\
\hline
\end{tabular}

growth and soil chemical properties, after wood ash applications were made to a typically nutrient poor soil with a low buffer capacity. The following hypothesis was formulated: tree survival and stand growth are not affected by $(A)$ ash application and (B) fertilization.

\section{Materials and methods}

\section{Site history}

The field study was situated on the Zululand coastal plain, at longitude $32^{\circ}$ East and latitude $28^{\circ}$ South. It was established approximately $7 \mathrm{~km}$ from central Richards Bay (KwaZulu-Natal, South Africa), positioned $12 \mathrm{~km}$ from the Indian Ocean at an altitude of $64 \mathrm{~m}$ above sea level. Data provided by the South African Weather Service for the last 25 years, estimated the trial area to have a mean annual temperature and mean annual precipitation of $22{ }^{\circ} \mathrm{C}$ and $1221 \mathrm{~mm}$, respectively. The experimental site has been afforested with Eucalyptus since the 1980's. The site was previously planted with an $E$. grandis $\times$ urophylla clone and reached rotation age near the end of 2012. The soil was classified as an arenosol. Arenosols are characteristically sandy textured and contain little organic matter and soils from the Zululand coastal plain typically fall into this category (du Toit et al. 2001, Smith \& du Toit 2005, Dovey et al. 2014). The basic soil chemical properties of the soil at the experimental site are shown in Tab. 1. The buffer capacity refers to the $\mathrm{mg} \mathrm{CaCO}$ per $\mathrm{kg}$ of soil that will raise the ambient $\mathrm{pH}$ by one unit, and the lime requirement refers to the tons of $\mathrm{CaCO}_{3}$ $\mathrm{ha}^{-1}$ that can react with soil to a soil depth of $0.3 \mathrm{~m}$ and raise the $\mathrm{pH}$ by one unit. Soil sample 2 was excluded from the buffer capacity and lime requirement determination.

\section{Experimental design and field trial establishment}

Wood ash application rates for the field trial were based on the results of a pilot study (a lime reaction study in the laboratory) on soil samples collected from the study site. The pilot study was based on the methodology by Aitken et al. (1990) and required the addition of a $\mathrm{CaCO}_{3}$ solution to the soil samples and then recording the $\mathrm{pH}$. The buffer capacity of each soil sample was determined by fitting linear regressions representing the relationship between the changes in soil $\mathrm{pH}$ and increasing rates of added $\mathrm{CaCO}_{3}$. Aitken et al. (1990) defines the buffer capacity as the change in quantity with intensity and, as a result, the reciprocal of the slope is recorded as the buffer capacity of the soil (Tab. 1). The buffer capacity was then used to determine the lime requirement and subsequently the wood ash application rate, using the calcium carbonate equivalent (CCE) approach (Bohn et al. 1979). In this experiment the lime requirement was defined as the amount of $\mathrm{CaCO}_{3}$ needed to raise the soil $\mathrm{pH}$ and did not necessarily mean the soil required lime before trial establishment.

Guided by the lime reaction in the pilot study, a field experiment was subsequently established, using a $4 \times 3$ factorial design in six replications, i.e., a total of 72 plots. The field experiment tested four wood ash application rates of $0,0.3,0.6$ and $1.2 \mathrm{t} \mathrm{ha}^{-1}$ in factorial combination with three levels of fertilizer, i.e., zero fertilizer, a conventional ammonium sulphate nitrate (ASN) fertilizer mixture or a NPK controlled release fertilizer mixture (see active ingredient contents in Tab. 2). Wood ash application rates were represented as $A_{0}, A_{0.3}, A_{0.6}$ and $A_{1.2}$, respectively. The controlled release fertilizer was polymer-coated to release approximately $25 \%$ of the contained nutrients up to 2 months and $75 \%$ up to 8 months after application. The controlled release fertilizer dosage of $320 \mathrm{~g}$ per seedling $\left(F_{C R F}\right)$ supplied $80 \mathrm{~g}$ of nitrogen and 20 $\mathrm{g}$ phosphorous (with some $\mathrm{Ca}, \mathrm{S}$ and trace elements) and was chosen as it yielded the 
best responses in recent experiments with controlled release fertilizers (Hans 2013). The conventional fertilizer ( $F_{\mathrm{cv}}$ treatment) supplied $40 \mathrm{~g} \mathrm{~N}$ as ammonium sulphate nitrate, and was chosen because it is a standard fertilizer recommendation for these soils (du Toit \& Oscroft 2003). Wood ash application rates were relatively low, due to the limited buffer capacity and the high initial $\mathrm{pH}$ of the soil.

A total of 72 plots were demarcated for this experiment. Trees were planted at a standard spacing of $2.4 \mathrm{~m} \times 3 \mathrm{~m}$. Individual plots comprised of $7 \times 7$ rows of trees and consisted of an outer and inner plot. Outer plots were designated as the buffer row, therefore data collection and sampling was limited to the inner plot. Inner plots consisted of the inner $5 \times 5$ rows and had an effective area of $180 \mathrm{~m}^{2}$.

The site was planted on 14 October 2013. Fertilization and wood ash applications commenced on 22 October 2013, 8 days after planting. First weeding was done on the $28^{\text {th }}$ January 2014 .

\section{Biomass index and growth response}

Diameters were measured at $1.3 \mathrm{~m}$ from the base (DBH) using diameter tapes at 8 and 21 months after trial establishment. Heights were measured at 8 and 21 months after trial establishment. Height rods, calibrated at $10 \mathrm{~cm}$, were used at 8 months of age and a Haglöf Vertex IV at 21 months. A Biomass Index (BI) was used as a substitute for calculating volume, due to the young age of the trial. This was done according to the methodology outlined by Donald et al. (1987); the BI was calculated as a product of the diameter at breast height squared $\left(\mathrm{cm}^{2}\right)$ and height $(\mathrm{m})$ of each tree per plot. The response was calculated from the $\mathrm{Bl}$ for each treatment and expressed as a percentage of the growth increase relative to the control treatment.

\section{Soil analysis}

\section{Sample collection}

Soil samples were collected at 4 and 8 months after trial establishment. A Beater auger was used to sample in the $0-10 \mathrm{~cm}$ soil surface mineral layer. The Beater auger is designed to take multiple, small diameter soil cores from the topsoil and bulking them per plot. Plots treated purely with wood ash (no fertilizer treatment) were selected for soil nutrient analyses and plots treated with the highest wood ash application of $1.2 \mathrm{t} \mathrm{ha}^{-1}$ were also subjected to heavy metal analysis.

\section{Soil nutrient analysis}

Soil samples were air dried and sieved through a $2 \mathrm{~mm}$ sieve; this additionally allowed for the determination of the stone fraction for each sample. The $\mathrm{pH}$ for each sample was determined in $1 \mathrm{M} \mathrm{KCl}$. Total $\mathrm{C}$ and $\mathrm{N}$ content was determined by means of high temperature combustion using the Leco Truspec ${ }^{\circledast} \mathrm{C}$ and $\mathrm{N}$ analyser. $\mathrm{P}$ content was determined using the Bray II method and extractable cations $\mathrm{K}, \mathrm{Ca}, \mathrm{Mg}$ and $\mathrm{Na}$ were extracted with $0.2 \mathrm{M}$ ammonium acetate solution ( $\mathrm{pH} 7)$. Extractable acidity was determined by titration with $0.05 \mathrm{M}$ $\mathrm{NaOH}$ after extraction with $1 \mathrm{M} \mathrm{KCl}$. Extracted solutions were analysed for chemical composition and elemental concentrations by Inductively Coupled Plasma Optical Emission Spectroscopy (ICP-OES). Total $\mathrm{P}$ was extracted at $80{ }^{\circ} \mathrm{C}$ for 30 minutes using a 1:1 mixture of $1 \mathrm{M}$ nitric and hydrochloric acid. Phosphorous concentration was determined using Varian ICP-OES. Effective cation exchange capacity (ECEC) was calculated as the sum of the base cation charge plus the extractable acidity at ambient $\mathrm{pH}$.

\section{Soil heavy metal analysis}

Individual samples were sieved ( $2 \mathrm{~mm}$ ) and then dried. Extraction was done by adding $20 \mathrm{ml} \mathrm{HNO}_{3}$ (55\%) and $5 \mathrm{ml} \mathrm{H}_{2} \mathrm{O}_{2}$ (30\%) to $5 \mathrm{~g}$ of each sample. These were then placed on a heated sandbed for 8 hours and then filtered using Whatman no. 2 filter paper. Extraction was done using atomic emission with Varian ICP-OES. Heavy metals were measured according to each element's wavelength.

\section{Foliar analysis}

\section{Sample collection}

Samples were collected at 4 and 8 months after trial establishment. Four young, fully expanded leaves were selected from each tree per plot and subsequently placed in a plastic bag and cooled to prevent deterioration. Foliar concentrations were assessed according to critical levels determined by Dell et al. (2001) for $E$. grandis $\times$ urophylla.

\section{Foliar nutrient analysis}

Samples were washed with a low concentration detergent solution (Teepol), rinsed with de-ionised water and oven dried at 70 ${ }^{\circ} \mathrm{C}$. The samples were then milled and ashed at $470{ }^{\circ} \mathrm{C}$. A $50: 50 \mathrm{HCl}(32 \%)$ solution

Tab. 3 - Elemental concentrations for 5 wood ash samples collected at different time intervals. (SE): standard error.

\begin{tabular}{|c|c|c|c|c|c|c|c|}
\hline \multirow{2}{*}{$\begin{array}{l}\text { Element/ } \\
\text { Parameter }\end{array}$} & \multicolumn{5}{|c|}{ Sample } & \multirow{2}{*}{ Mean } & \multirow{2}{*}{ SE } \\
\hline & A1 & A2 & A3 & A4 & A5 & & \\
\hline $\mathrm{C}\left(\mathrm{g} \mathrm{kg}^{-1}\right)$ & 93.0 & 45.7 & 170.7 & 73.4 & 44.5 & 85.5 & 23.2 \\
\hline$N\left(\mathrm{~g} \mathrm{~kg}^{-1}\right)$ & 0.4 & 0.2 & 0.8 & 0.3 & 0.5 & 0.4 & 0.1 \\
\hline$P\left(\mathrm{~g} \mathrm{~kg}^{-1}\right)$ & 8.9 & 6.4 & 12.4 & 8.6 & 3.6 & 8.0 & 1.5 \\
\hline $\mathrm{K}\left(\mathrm{g} \mathrm{kg}^{-1}\right)$ & 37.2 & 37.8 & 82.3 & 20.4 & 12.3 & 38.0 & 12.1 \\
\hline $\mathrm{Ca}\left(\mathrm{g} \mathrm{kg}^{-1}\right)$ & 292.7 & 199.1 & 173.8 & 272.4 & 84.0 & 204.4 & 37.3 \\
\hline$M g\left(\mathrm{~g} \mathrm{~kg}^{-1}\right)$ & 37.0 & 21.3 & 173.8 & 33.0 & 9.1 & 54.8 & 30.1 \\
\hline $\mathrm{Na}\left(\mathrm{mg} \mathrm{kg}^{-1}\right)$ & 11867 & 9275 & 20723 & 8171 & 4046 & 10816 & 2779 \\
\hline$M n\left(\mathrm{mg} \mathrm{kg}^{-1}\right)$ & 7160 & 2803 & 4534 & 6110 & 1320 & 4385 & 1063 \\
\hline $\mathrm{Fe}\left(\mathrm{mg} \mathrm{kg}^{-1}\right)$ & 1754 & 7699 & 3411 & 1254 & 2117 & 3247 & 1169 \\
\hline $\mathrm{Cu}\left(\mathrm{mg} \mathrm{kg}^{-1}\right)$ & 28 & 57 & 92 & 87 & 85 & 70 & 12 \\
\hline $\mathrm{Al}\left(\mathrm{mg} \mathrm{kg}^{-1}\right)$ & 1742 & 5419 & 2769 & 856 & 1440 & 2445 & 806 \\
\hline Moisture (\%) & 0.10 & 0.29 & 0.60 & 1.20 & 0.50 & 0.54 & 0.19 \\
\hline $\mathrm{pH}$ & 12.76 & 11.99 & 12.14 & 13.40 & 13.40 & 12.74 & 0.30 \\
\hline
\end{tabular}

was mixed into each ashed sample and extraction was done using filter paper. The $\mathrm{N}$ content was determined by means of combustion in a Leco $\mathrm{N}$-analyser. Micronutrients and cation concentrations of the extract was measured with Varian ICP-OES.

\section{Foliar heavy metal analysis}

Foliage samples were ashed and extracted using similar methodology to the foliar nutrient analysis procedure. After ashing and extraction, the aliquot was transferred to a $20 \mathrm{ml} \mathrm{ICP}$ tube and analysed using Varian ICP-OES. Heavy metal content was determined according to each element's wavelength.

\section{Wood ash analysis}

\section{Wood ash elemental composition}

Ash was supplied by DukuDuku sawmill, situated approximately $10 \mathrm{~km}$ from St. Lucia. The mill generated pure wood ash from the combustion of Eucalyptus off-cuts and waste (e.g., sawdust) produced during timber processing. Five wood ash samples were collected periodically at three intervals to account for variation in composition (Tab. 3). This variation could be caused by site, species and silvicultural treatments in the plantation, as well as variations in the combustion process on the specific day.

\section{Analysis procedure}

Fresh wood ash samples were selected for total $\mathrm{C}, \mathrm{N}$ and $\mathrm{S}$ determination using the Dumas dry combustion method. Samples were burnt at $1350{ }^{\circ} \mathrm{C}$ in a furnace, converting elemental carbon, nitrogen and sulphur into gasses. The gasses produced from combustion were homogenised and passed through infrared detection $\left(\mathrm{CO}_{2}\right.$ and $\left.\mathrm{SO}_{2}\right)$ and thermal conductivity cells $\left(\mathrm{N}_{2}\right.$ and $\mathrm{NO}_{x}$ ) to measure the elemental $\mathrm{C}$ and $\mathrm{N}$ contents. The elemental concentrations of $\mathrm{Ca}, \mathrm{Mg}, \mathrm{K}, \mathrm{Na}, \mathrm{P}, \mathrm{Cu}, \mathrm{Zn}, \mathrm{Mn}, \mathrm{Fe}$ and $\mathrm{Al}$ were determined using the Inductively Coupled Plasma Optical Emission Spectroscopy (ICP-OES). Heavy metal concentrations were determined using Inductively 
Fig. 1 - Biomass Index at 21 months of age for the main effect of fertilizer type. Standard error $(p<0.05)$ is shown by whiskers.
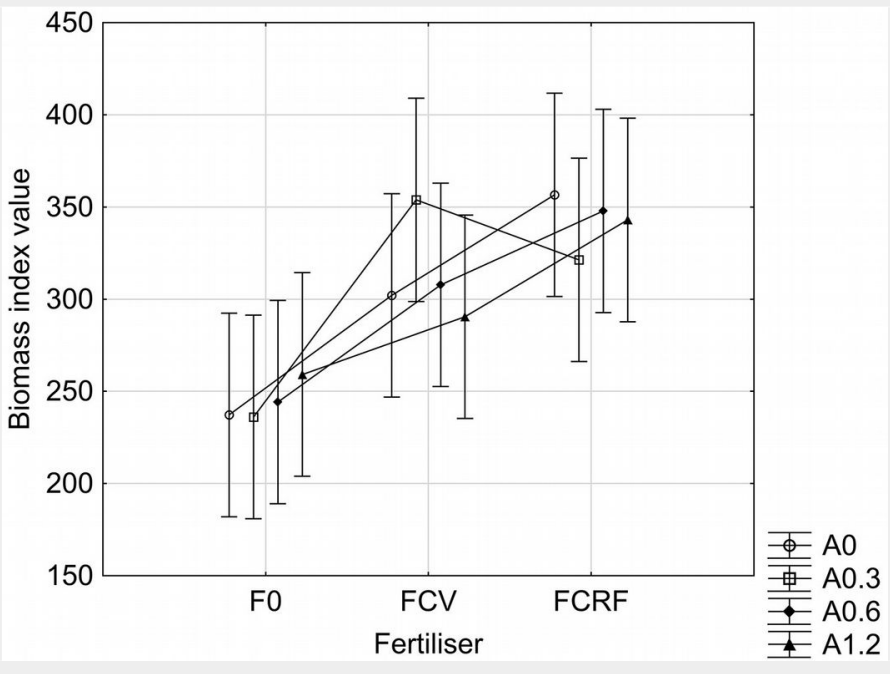

Coupled Plasma Atomic Emission Spectroscopy (ICP-AES); the wavelengths of each tested heavy metal were used to determine the concentrations.

\section{Statistical analysis}

The effects of wood ash application rate and fertilizer variety on $E$. grandis $\times$ urophylla growth were analysed by the analysis of variance (ANOVA). A least significant difference $\left(\mathrm{LSD}_{5 \%}\right)$ was used to show any significant interaction among treatments if the F statistic was significant for the treatment effect. Treatments with $p<0.05$ were reported as having statistical significance, unless stated otherwise. Data was initially tested for normality using the Shapiro-Wilk test and Normal Probability plots. Homogeneity was tested using Bartlett's and Levene's tests. Fischer's LSD test was used to compare specific treatment differences for data collected at 4, 8 and 21 months. Data analysis was completed using the software STATISTICA ${ }^{\circledast}$ v.11.0 (StatSoft inc., Tulsa, OK, USA). In all instances, we used were reported.

\section{Results}

\section{Seedling survival} fertilizer ( $\left.F_{c v} ; 98.8 \%\right)$. the factorial structure of the treatments in the experiment to ascertain if there were any interactions. In cases where there were no interactions, the main effects

A blanking operation was implemented one week prior to treatment implementation and as a result the initial survival was $100 \%$. At 629 days after treatment implementations (approximately 21 months) tree survival was $95.0 \%$. The main effect of wood ash application rate, at both time intervals, and the interaction for time after planting and fertilizer type were not statistically significant. However, the main effect of fertilizer type on survival was significant $(p=0.006)$. Average survival was lowest for untreated plots $\left(F_{0} ; 98.0 \%\right)$, followed by plots treated with controlled release fertilizer $\left(\mathrm{F}_{\mathrm{CRF}} ; 98.2 \%\right)$ and lastly conventional

Fig. 2 - Mean biomass indices for ash and fertilizer treatment combinations at 21 months after treatment implementation. The $x$-axis for the wood ash treatment is spaced out to reflect

the scale of the actual increments in ash application.

Standard error $(p<0.05)$ is shown by whiskers.

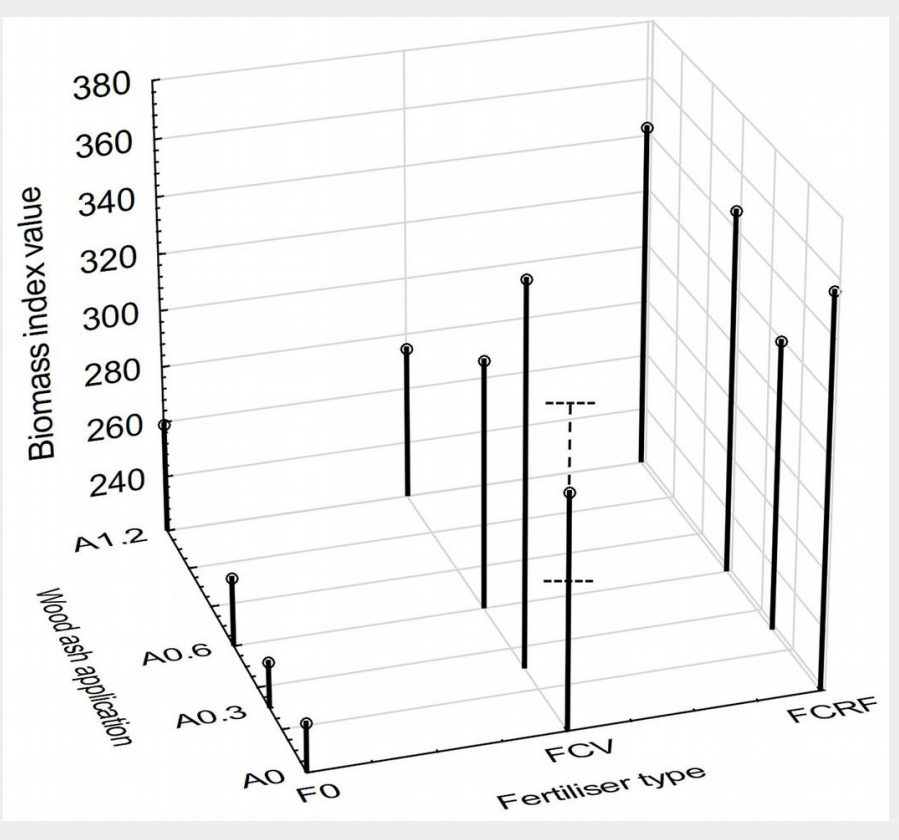

Height growth

The effect of wood ash treatment on height growth was not significant, and there were no significant interactions between factors. The average height growth per plot was statistically significant $(p<$ 0.001 ) for fertilizer type as a main effect at 8 and 21 months after treatment implementation. At 8 months of age, plots treated with $\mathrm{F}_{\mathrm{CRF}}$ had the greatest mean height \pm standard error of mean, followed by $F_{\mathrm{CV}}$ and lastly $\mathrm{F}_{\mathrm{o}}$ treated plots $(267.8 \pm$ $8.1,239.8 \pm 5.3$ and $201.3 \pm 7.3 \mathrm{~cm}$, respectively). Similarly, at 21 months $F_{\text {CRF }}$ treated plots had the greatest mean height growth, followed by $F_{c v}$ and $F_{0}$ treated plots, with mean heights of $678.8 \pm 12.7$, $656.8 \pm 13.0$ and $607.8 \pm 13.2 \mathrm{~cm}$, respectively.

\section{Diameter growth}

The effect of wood ash treatment on diameter growth was not significant, and there were no significant interactions between factors. The main effect for fertilizer type on diameter growth was statistically significant $(p<0.0001)$ at 8 and 21 months after treatment implementation. At 8 months, plots treated with $\mathrm{F}_{\mathrm{CRF}}$ had the largest mean diameter \pm standard error of mean of $2.12 \pm 0.09 \mathrm{~cm}$. $F_{\mathrm{cv}}$ treatments had a mean diameter of $1.74 \pm 0.03 \mathrm{~cm}$ and $F_{0}$ treated plots a mean value of $1.28 \pm 0.07$ $\mathrm{cm}$. At 21 months, $\mathrm{F}_{\mathrm{CRF}}$ treated plots had the greatest mean diameter value of $6.74 \pm$ $0.09 \mathrm{~cm}$, followed by $F_{c v}$ and $F_{0}$ treated plots with mean diameters of $6.63 \pm 0.11$ and $5.84 \pm 0.10 \mathrm{~cm}$, respectively.

\section{Biomass index and $\mathrm{BI}$ growth response}

The main effect of wood ash application rate and the interaction for wood ash application rate and fertilizer type was not statistically significant at 8 and 21 months. However, the effect of fertilizer type on the $\mathrm{BI}$ at 8 months was weakly significant on a $90 \%$ confidence interval $(p=0.081)$. Mean $\mathrm{BI}$ was highest for $\mathrm{F}_{\mathrm{CRF}}$ treated plots and lowest for $F_{0}$ treatments $(22.92 \pm 6.09$ and $6.16 \pm 0.60$, respectively).

At 21 months of age, the main effect of fertilizer type was significant $(p<0.001)$ on a $95 \%$ confidence interval. At 21 months of age, $\mathrm{BI}$ was highest for $\mathrm{F}_{\mathrm{CRF}}$ treated plots and lowest for $F_{0}$ treated pots, but the difference in $\mathrm{BI}$ for $\mathrm{F}_{\mathrm{CRF}}$ and $\mathrm{F}_{\mathrm{CV}}$ treated plots was minor, with respective mean \pm standard error of mean values of $342.20 \pm 13.53$, $313.57 \pm 11.12$ and $244.21 \pm 15.03$. Similar to the 8 month data, the effect of the ash applications on BI growth was not statistically significant (Fig. 1), but a significant effect was visible for type of fertilizer used in the experiment.

At 8 months after treatment implementation, the highest mean growth response of $683 \%$ over the control was recorded for plots treated with $A_{0.6} F_{C R F}$ (Fig. 2). Plots treated with no fertilizer and purely wood ash had the smallest growth response. At 21 months after treatment implementation, 
Tab. 4 - Soil C, ECEC, exchangeable acidity, mean base cation concentrations and respective standard error values at 4 and 8 months after treatment implementation.

\begin{tabular}{|c|c|c|c|c|c|c|c|c|}
\hline Period & Parameter & C (\%) & $\begin{array}{c}\mathrm{K} \\
\left(\mathrm{cmol}_{\mathrm{c}} \mathrm{kg}^{-1}\right)\end{array}$ & $\begin{array}{c}\mathrm{Ca} \\
\left(\mathrm{cmol}_{\mathrm{c}} \mathrm{kg}^{-1}\right)\end{array}$ & $\begin{array}{c}\mathrm{Mg} \\
\left(\mathrm{cmol}_{\mathrm{c}} \mathrm{kg}^{-1}\right)\end{array}$ & $\begin{array}{c}\mathrm{Na} \\
\left(\mathrm{cmol}_{\mathrm{c}} \mathrm{kg}^{-1}\right)\end{array}$ & $\begin{array}{c}\text { Extractable } \\
\text { acidity }\left(\mathrm{cmol}_{\mathrm{c}} \mathrm{kg}^{-1}\right)\end{array}$ & $\begin{array}{c}\text { ECEC } \\
\left(\mathrm{cmol}_{\mathrm{c}} \mathrm{kg}^{-1}\right)\end{array}$ \\
\hline \multirow[t]{2}{*}{4 months } & Mean & 0.39 & 0.062 & 1.991 & 0.498 & 0.054 & 0.338 & 2.943 \\
\hline & SE & 0.14 & 0.004 & 0.209 & 0.020 & 0.002 & 0.020 & 0.255 \\
\hline \multirow[t]{2}{*}{8 months } & Mean & 0.19 & 0.045 & 1.182 & 0.322 & 0.037 & 0.263 & 1.849 \\
\hline & SE & 0.05 & 0.002 & 0.065 & 0.011 & 0.001 & 0.013 & 0.092 \\
\hline
\end{tabular}

the mean growth response was highest for the $\mathrm{A}_{0} \mathrm{~F}_{\mathrm{CRF}}$ treatments; a $50.3 \%$ increase relative to the control treatments. A negative growth response of $-0.5 \%$ was found for the $A_{0.3} F_{0}$ treatment, but this was statistically similar to the untreated control. Similar to the 8 month data, the weakest growth responses were found for treatments that received no fertilizer and purely wood ash. The $A_{0.3} F_{0}, A_{0.6} F_{0}$ and $A_{1.2} F_{0}$ treatments had responses of $-0.5 \%, 2.9 \%$ and $9.2 \%$, respectively, relative to the control.

\section{Effect of ash application on topsoil}

Soil analyses were performed on data gathered at 4 and 8 months after trial establishment on samples collected from 0 to $10 \mathrm{~cm}$ soil depth.

\section{Soil C}

Mean carbon content differed significantly $(p<0.001)$ for the fixed effect of time after trial establishment. At 4 months, mean soil carbon content was $0.39 \%$ and at 8 months after trial establishment, mean soil carbon content decreased to $0.19 \%$ (Tab. 4).

\section{ECEC, exchangeable acidity and base cations}

Exchangeable base cations and effective cation exchange capacity were significantly different for the fixed effect of time after treatment implementation. ECEC decreased from 4 to 8 months after treatment implementation months (Tab. 4); in 4 months ECEC decreased from 2.94 to 1.88 $\mathrm{cmol}_{\mathrm{c}} \mathrm{kg}^{-1}$. Extractable acidity decreased from 0.34 to $0.26 \mathrm{cmol}_{\mathrm{c}} \mathrm{kg}^{-1}$ for the same period.

Mean values of exchangeable $\mathrm{Ca}^{2+}, \mathrm{Mg}^{2+}$, $\mathrm{Na}^{+}$and $\mathrm{K}^{+}$concentrations decreased from 4 to 8 months. Mean $\mathrm{Ca}^{2+}$ concentration was significantly higher at 4 months after trial establishment and showed a decrease by 8 months, i.e., from 2.00 to $1.18 \mathrm{cmol}_{\mathrm{c}}$ $\mathrm{kg}^{-1}$. Between 4 and 8 months mean $\mathrm{Ca}^{2+}$ concentration decreased by $0.81 \mathrm{cmol}_{\mathrm{c}} \mathrm{kg}^{-1}$, this decrease was indicative of the temporary effect of wood ash additions on soil $\mathrm{Ca}^{2+}$ concentrations in the topsoil (Tab. 4). The mean $\mathrm{Mg}^{2+}$ soil concentration was 0.50 $\mathrm{cmol}_{\mathrm{c}} \mathrm{kg}^{-1}$ at 4 months after trial establishment and $0.32 \mathrm{cmol}_{\mathrm{c}} \mathrm{kg}^{-1}$ at 8 months. During this 4 month period, mean $\mathrm{Mg}^{2+}$ concentration decreased by $0.18 \mathrm{cmol}_{\mathrm{c}} \mathrm{kg}^{-1}$. Mean $\mathrm{Na}^{+}$concentration was greatest at 4 months after trial establishment and showed a decrease at 8 months, 0.05 to
$0.04 \mathrm{cmol}_{\mathrm{c}} \mathrm{kg}^{-1}$. Mean $\mathrm{Na}^{+}$concentration liming effect during the first part of the decreased by $0.02 \mathrm{cmol}_{\mathrm{c}} \mathrm{kg}^{-1}$ during the 4 experimental period. month period (Tab. 4). Mean exchangeable $\mathrm{K}^{+}$cation concentration did not vary considerably at 4 months and 8 months after trial establishment, but were significant. The mean concentration was $0.06 \mathrm{cmol}_{c}$ $\mathrm{kg}^{-1}$ at 4 months and $0.05 \mathrm{cmol}_{\mathrm{c}} \mathrm{kg}^{-1}$ at 8 months after trial establishment. Mean $\mathrm{K}^{+}$ concentration decreased by $0.02 \mathrm{cmol}_{\mathrm{C}} \mathrm{kg}^{-1}$ during the 4 month period (Tab. 4).

\section{Soil pH}

The changes in soil $\mathrm{pH}$ were significant for the fixed effect of time after treatment implementation (Fig. 3). Wood applications did not significantly affect the soil $\mathrm{pH}$, and Fig. 3 provides an illustration of this for the highest and lowest (control) application rates over the experimental period. The mean $\mathrm{pH}$ increased from 5.5 to 6.1 in the first 4 months, and decreased to 5.7 from 4 to 8 months, indicating a small temporary

\section{Heavy metal concentrations}

Results indicated significant treatment differences $(p=0.001)$ for the fixed effect of time on soil heavy metal concentrations. Heavy metal concentrations for $\mathrm{Cd}, \mathrm{Hg}, \mathrm{Pb}$ and $\mathrm{Cr}$ increased significantly from 4 to 8 months, but were well below the screening values set by the National Environmental Management: Waste Act, 2008 (Act no. 59 of 2008) of South Africa for protection of ecosystem health and the European Union (Herselman 2007 - Tab. 5). At both intervals, mean $\mathrm{Cr}$ concentrations were found to be the highest in the soil and mean cadmium concentrations were nearly undetectable (Tab. 5). At 4 months, mean $\mathrm{Cr}$ and $\mathrm{Cd}$ concentrations were $<0.001 \mathrm{mg} \mathrm{kg}^{-1}$ and $0.008 \mathrm{mg} \mathrm{kg}^{-1}$, respectively. At 8 months, concentrations were $2.215 \mathrm{mg} \mathrm{kg}^{-1}$ and 7.375 $\mathrm{mg} \mathrm{kg}^{-1}$, respectively.

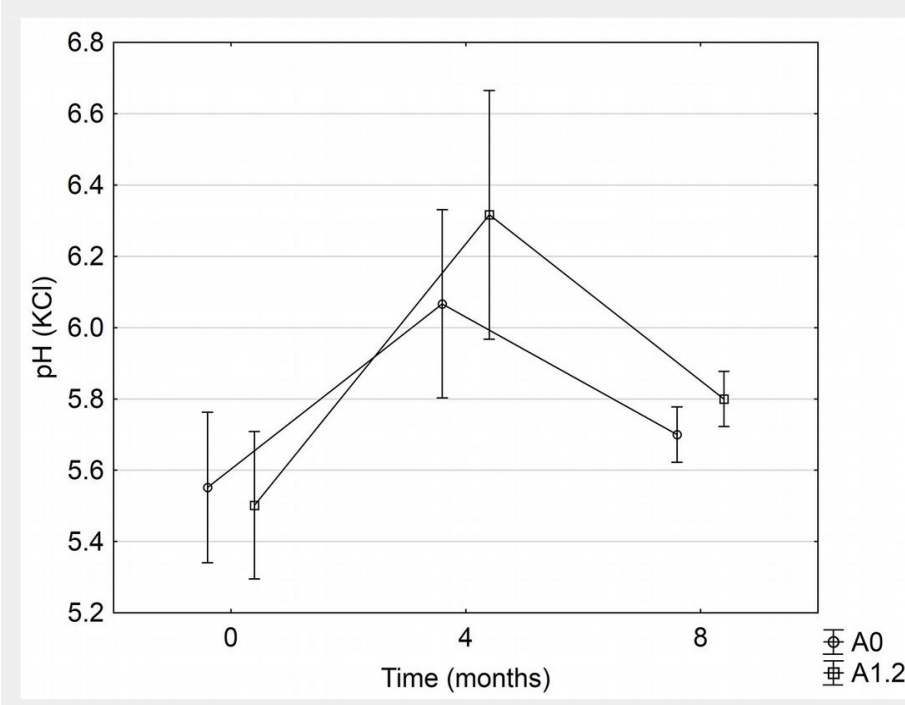

Fig. 3 - Significant soil pH changes over time, for the highest and lowest wood ash application rates. Standard error $(p<0.05)$ is shown by whiskers.

Tab. 5 - Mean and standard error of mean soil heavy metal concentrations at 4 and 8 months after establishment.

\begin{tabular}{llcccc}
\hline Period & Parameter & $\begin{array}{c}\mathrm{Cd} \\
\left(\mathbf{m g ~ k g}^{-1}\right)\end{array}$ & $\begin{array}{c}\mathrm{Hg} \\
\left(\mathbf{m g ~ k g}^{-1}\right)\end{array}$ & $\begin{array}{c}\mathrm{Cr} \\
\left(\mathbf{m g ~ k g}^{-1}\right)\end{array}$ & $\begin{array}{c}\mathrm{Pb} \\
\left(\mathbf{m g ~ k g}^{-1}\right)\end{array}$ \\
\hline 4 months & Mean & 0.000 & 0.009 & 2.215 & 0.965 \\
& SE & 0.000 & 0.002 & 0.114 & 0.060 \\
\multirow{2}{*}{ months } & Mean & 0.008 & 0.029 & 7.375 & 3.859 \\
& SE & 0.004 & 0.003 & 0.515 & 0.238 \\
Allowable soil & NEMA - South Africa & 37 & 4.1 & $260(\mathrm{Cr} \mathrm{VI)}$ & 100 \\
metal levels & European Union & $1-3$ & $1-1.5$ & - & $50-300$ \\
\hline
\end{tabular}




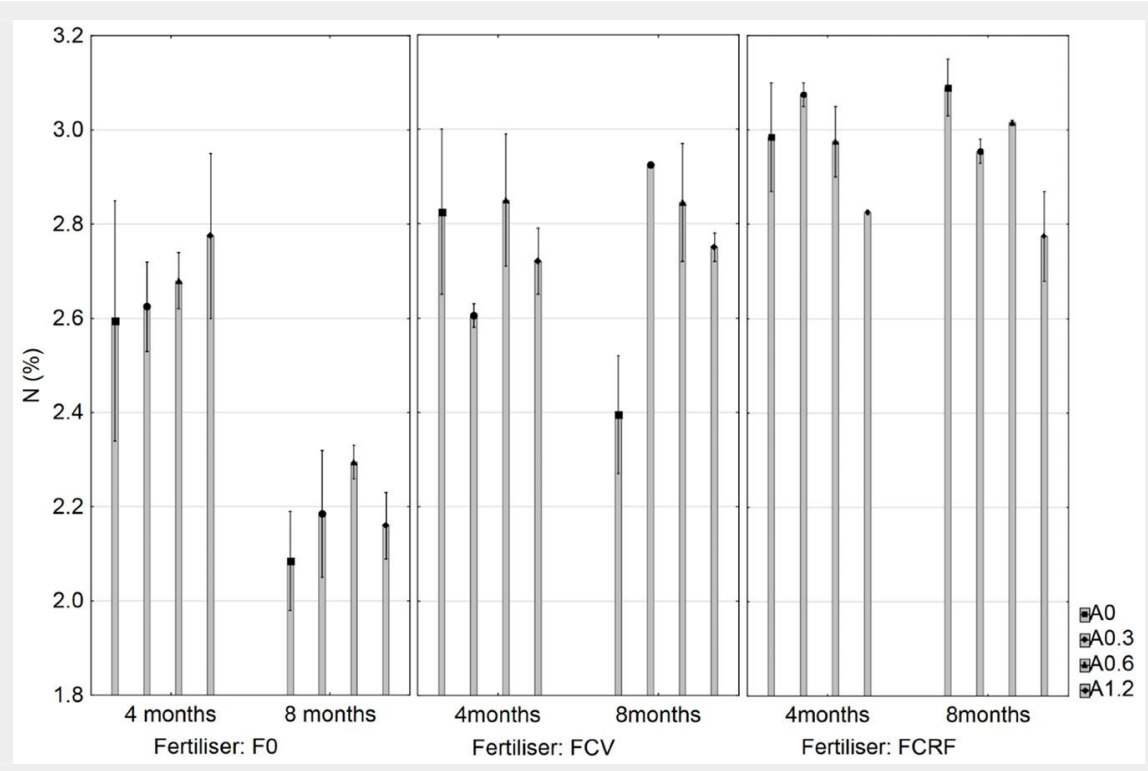

Fig. 4 - Mean foliar $\mathrm{N}$ concentrations for the effects of fertilizer, time and wood ash application rate. Standard error $(p<0.05)$ is shown by whiskers.

\section{Foliar analysis}

\section{Critical levels and nutrient concentrations}

Several plots showed sub-optimal foliar $P$, $\mathrm{K}$ and $\mathrm{Zn}$ concentrations at 4 months of age according to the critical value assessment method (Dell et al. 2001). They were defined as sub-optimal, due to concentrations below the critical values suggested by Dell et al. (2001), but not near acute deficiency levels. At 8 months after treatment implementation, several plots showed potentially sub-optimal $\mathrm{P}$ and $\mathrm{K}$ concentrations. Mean $\mathrm{N}$ concentration was the only nutrient significantly affected by time, fertilizer and the interaction of wood ash with both variables $(p=0.005)$. At 4 to 8 months after treatment implementation, mean foliar $\mathrm{N}$ concentration decreased significantly by $0.17 \%$ for unfertilized plots (Fig. 4). Mean $\mathrm{N}$ concentrations remained fairly stable over time for $F_{C R F}, F_{C V}$ treatments and all the tested wood ash application rates (Fig. 4).

Significant treatment differences were found for the single effect of fertilizer type on mean foliar $\mathrm{P}$ concentration $(p=0.016)$. Plots treated with $F_{C R F}$ had the greatest mean $\mathrm{P}$ concentration and $\mathrm{F}_{\mathrm{CV}}$ treatments the lowest, namely $0.197 \%$ and $0.171 \%$, respectively. Significant treatment differ- ences were found for the interaction of fertilizer type and time after treatment implementation on mean $\mathrm{K}$ concentration; at 4 months the mean concentration was highest for $F_{0}$ treated plots and lowest at 8 months for $F_{\mathrm{CRF}}$ treatments, namely $1.13 \%$ and $0.95 \%$, respectively (details not presented).

The critical value nutrient assessment technique identified a single treatment with a sub-optimal $\mathrm{Zn}$ and $\mathrm{P}$ concentration at both age intervals and thus did not provide enough evidence to suggest potentially severe macro or micronutrient imbalances could ensue from wood ash applications of up to $1.2 \mathrm{t} \mathrm{ha}^{-1}$ (details not presented).

\section{Heavy metal concentrations}

Treatments with the highest wood ash applications were selected for heavy metal analyses. At 4 months of age, $\mathrm{Cd}$ was undetectable and $\mathrm{Hg}, \mathrm{Cr}$ and $\mathrm{Pb}$ concentrations were in the range of 0.01 to $0.02 \mathrm{mg} \mathrm{kg}^{-1}$. At 8 months, $\mathrm{Cd}$ was yet again undetectable and $\mathrm{Hg}, \mathrm{Pb}$ and $\mathrm{Cr}$ concentrations ranged from 0.01 to $0.04 \mathrm{mg} \mathrm{kg}^{-1}$ (Tab. 6). Arsenic, $\mathrm{Hg}$ and $\mathrm{Pb}$ have a low bio-availability (Laidlaw et al. 2012) and this could likely serve as an explanation for the observed concentrations. Cadmium, $\mathrm{Hg}, \mathrm{Cr}$ and $\mathrm{Pb}$ values for

Tab. 6 - Foliar heavy metal concentrations (in $\mathrm{mg} \mathrm{kg}^{-1}$ ) for selected plots treated with $1.2 \mathrm{t} \mathrm{ha}^{-1}$ wood ash at 4 and 8 months of age.

\begin{tabular}{lcccccccc}
\hline $\begin{array}{l}\text { Treat- } \\
\text { ment }\end{array}$ & \multicolumn{3}{c}{ 4 months $\left(\mathbf{m g ~ k g}^{-1}\right)$} & \multicolumn{7}{c}{ 8 months $\left(\mathbf{m g ~ k g}^{-1}\right)$} \\
\cline { 2 - 9 } & $\mathbf{C d}$ & $\mathbf{H g}$ & $\mathbf{C r}$ & $\mathrm{Pb}$ & $\mathrm{Cd}$ & $\mathbf{H g}$ & $\mathrm{Cr}$ & $\mathrm{Pb}$ \\
\hline $\mathrm{A}_{1.2} \mathrm{~F}_{0}$ & 0.0 & 0.01 & 0.02 & 0.01 & 0.0 & 0.01 & 0.04 & 0.00 \\
$\mathrm{~A}_{1.2} \mathrm{~F}_{0}$ & 0.0 & 0.02 & 0.02 & 0.00 & 0.0 & 0.00 & 0.04 & 0.01 \\
$\mathrm{~A}_{1.2} \mathrm{~F}_{\mathrm{CV}}$ & 0.0 & 0.01 & 0.02 & 0.00 & 0.0 & 0.00 & 0.04 & 0.01 \\
$\mathrm{~A}_{1.2} \mathrm{~F}_{\mathrm{CV}}$ & 0.0 & 0.01 & 0.01 & 0.00 & 0.0 & 0.01 & 0.04 & 0.00 \\
$\mathrm{~A}_{1.2} \mathrm{~F}_{\mathrm{CRF}}$ & - & - & - & - & 0.0 & 0.00 & 0.04 & 0.01 \\
$\mathrm{~A}_{1.2} \mathrm{~F}_{\mathrm{CRF}}$ & 0.0 & 0.01 & 0.02 & 0.00 & 0.0 & 0.00 & 0.04 & 0.00 \\
\hline
\end{tabular}

the $A_{1.2} F_{C R F}$ treatment were not determined at 4 months.

\section{Discussion}

\section{Mortality}

The main effect of wood ash application rate on seedling mortality was not significant. However, at 8 and 21 months after trial establishment, seedling mortality was significantly greater for plots that received no supplementary nutrients from fertilization. This may partly be due to the poor nutrient status of the soils, potentially exacerbated by ash applications with low $\mathrm{N}$. The results suggest that the wood ash (in the absence of NPS fertilizer) was not able to entirely supply the seedlings with the necessary nutrients for increased survival during the nutrient-demanding growth phase that commonly occurs at time of establishment (Laclau et al. 2003).

\section{Growth response}

The growth responses observed at 8 months of age showed that applications of purely wood ash or fertilizer did not suppress growth for any treatments, bearing in mind the magnitude of the responses and weak significance. However, at 21 months of age, the $A_{0.3} F_{0}$ treated plots had a small negative growth response of $-0.50 \%$ relative to the control treatment at the respective age. This was noted for single treatments that purely received $0.3 \mathrm{t} \mathrm{ha}^{-1}$ wood ash and no supplementary nutrients from fertilization. This degree of the response was such that there was statistically no difference between the treatment and the control. Growth suppression from wood ash additions in excess of $5 \mathrm{t} \mathrm{ha}^{-1}$ to Picea abies forests has been reported by Mandre et al. (2004). In our trial, it was unlikely that the negative growth response resulted from an over-application of wood ash, since the higher application levels did not suppress growth. This experiment showed that wood ash has the potential to increase the growth of eucalypts, but the effect of wood ash was insignificant on the biomass index and a balance nutrient supplement was needed to obtain a significant increase in growth (Fig. 1). Guerrini et al. (2000) found that wood ash and paper sludge applications on predominantly sandy soils can increase growth in the range of $38 \%$ to $64 \%$ relative to chemical fertilizers. The addition of a supplementary nitrogen-rich nutrient source has been shown to increase growth and is recommended if improved growth responses are anticipated from wood ash additions (Demeyer et al. 2001, Jacobson 2003, Elliott \& Mahmood 2006).

\section{Soil properties}

\section{Soil pH}

A temporary liming effect was observed for the 8 month monitoring period. Soil analyses at 0, 4 and 8 months showed 
respective mean $\mathrm{pH}$ values of 5.5, 6.1 and 5.7 (Fig. 3). The temporary fluctuation in soil $\mathrm{pH}$ could likely have been attributed to the low intensity burn at site establishment and the resultant moderate slash retention before treatments were implemented. Du Toit et al. (2008) found that topsoil pH increased significantly after clear felling and re-establishment of an $E$. grandis plantation, grown on a humic ferralsol (treatments where slash was retained showed a modest increase and slash burning elicited a larger increase in $\mathrm{pH}$ ). In that trial, topsoil $\mathrm{pH}$ increased during the first 2 years after re-establishment and returned to initial levels when re-measured at rotation end (7 years). Although the longer term effect of wood ash on soil $\mathrm{pH}$ was not significant, it is worth noting that wood ash incubation studies by Ohno \& Erich (1994) also found that soil $\mathrm{pH}$ increased for the first 25 weeks and gradually declined as time progressed; soil $\mathrm{pH}$ stabilised at 42 weeks after that experiment was initiated.

\section{Soil $\mathrm{C}$ and macronutrients}

Mean soil $C$ decreased from 4 to 8 months. Soil C was nearly $50 \%$ less at 8 months relative to the previous measurements. Comparable results were obtained by Gonçalves et al. (2008), working on a eucalypt stand situated on a haplic ferralsol in Brazil with $77 \%$ sand content: they recorded a decrease in organic matter contents in the top $5 \mathrm{~cm}$ of the soil of 22.2 to $14.9 \mathrm{mg} \mathrm{g}^{-1}(33 \%)$ over a 10 month period following clear felling and burning. It is possible that a substantial amount of topsoil carbon was lost due to the surface fires and subsequent wind erosion, as the site is situated close to the coast with strong winds in spring (August to November). The carbon content of the higher ash applications was roughly two orders of magnitude smaller than the carbon pool of the $0-10$ $\mathrm{cm}$ soil layer, and for this reason, the effect of our wood ash applications on soil organic carbon levels were insignificant.

Although there were no statistically significant effects for individual wood ash treatments on extractable soil phosphate and potassium concentrations, the short term nutrient fluctuations over time were of note. The elevated levels of phosphorous at 4 months followed by a significant reduction by 8 months is a pattern often observed in acid or moderately acid forest soils following slash burning: a temporary increase in plant-available $\mathrm{P}$ which coincides with a temporary rise in soil $\mathrm{pH}$, in the so-called ash-bed effect (Romanyà et al. 1994, du Toit et al. 2008). The higher temperatures, changes in soil moisture and soil $\mathrm{pH}$ could stimulate microbial organisms responsible for $\mathrm{P}$ mineralisation and decomposition and result in larger $\mathrm{P}$ concentrations (Neary et al. 1999, Nadel et al. 2007). Soil $P$ is increasingly fixated by $\mathrm{Fe}^{2+}$ and $\mathrm{Al}^{3+}$ compounds at $\mathrm{pH}$ values smaller than 6 and is also rendered unavailable by the formation of sparingly-soluble calcium and magnesium phosphates at $\mathrm{pH}$ values exceeding 7 (Bohn et al. 1979). The buffering capacity of a soil is central in determining the rise in soil $\mathrm{pH}$ from the application of a liming material. The application of a liming material on a low buffered soil can reduce $P$ anion availability, due to the alkalinity and the high $\mathrm{Ca}^{2+}$ additions to the soil (Bohn et al. 1979). In addition, some $P$ could have leached from the soil given the high leaching ability of a sandy soil.

\section{Exchangeable base cations and CEC}

Calcium cation concentrations were the highest of the soil base cations (Tab. 4) and it also displayed the largest change from 4 to 8 months after trial establishment. This may be attributed to the burning of wood harvesting residue, as well as wood ash composition, as the wood ash used in the experiment contained a significant amount of $\mathrm{Ca}$. The addition of large quantities of divalent $\mathrm{Ca}^{2+}$ in the form of wood ash on the soil possibly displaced the monovalent cations $\mathrm{Na}^{+}$and $\mathrm{K}^{+}$and ions with a smaller mass and ionic radius like $\mathrm{Mg}^{2+}$. The decreases in total soil $\mathrm{K}^{+}, \mathrm{Mg}^{2+}$ and $\mathrm{Na}^{+}$concentrations observed after 8 months deviated from most of the documented wood ash-soil responses. Guerrini et al. (2000) found that the combined application of wood ash and sludge can induce $\mathrm{Ca}^{2+}: \mathrm{K}^{+}$soil imbalances and result in acute foliar $\mathrm{K}$ deficiencies. This was not observed in our experiment, probably because of the lower ash applications.

The significant CEC decreases observed at 8 months was likely a product of decreased soil carbon contents in the same interval. The elevated levels of ECEC at 4 months could have stemmed from the slash burning operation which may have resulted in a temporarily increase in CEC from variable charge sources (Giardina et al. 2000, du Toit et al. 2008). After 8 months the CEC likely returned back to initial levels. Organic carbon greatly affects soil CEC and can be responsible for up to $80 \%$ of the CEC in highly weathered soils (Soares \& Alleoni 2008).

\section{Foliar nutrient levels}

\section{Foliar macronutrients}

Initially a foliar $\mathrm{N}$ limitation was expected given the chemical properties of the wood ash, but foliar analyses showed that the $F_{\mathrm{CRF}}$ and $F_{\mathrm{CV}}$ used in the experiment was able to sustain adequate $\mathrm{N}$ levels. After 8 months, $F_{\mathrm{CRF}}$ outperformed $\mathrm{F}_{\mathrm{CV}}$ and was able to maintain higher and slightly more uniform foliar $\mathrm{N}$ concentrations over time. However, the critical value nutrient assessment method by Dell et al. (2001) showed a strong likelihood that sub-optimal and deficient $\mathrm{P}$ and $\mathrm{K}$ foliar concentrations can be expected from wood ash additions. The significant decline in mean foliar $\mathrm{P}$ in the 4 and 8 month monitoring period was similar to results found by Ohno \& Erich (1990, 1994). Incubation studies by Ohno \& Erich
(1994) found that wood ash temporarily increases $\mathrm{P}$ and $\mathrm{K}$ plant availability, but the effects were brief and concentrations declined after the first 25 weeks. In a similar experiment, Ohno \& Erich (1990) concluded that the best predictor for $\mathrm{P}$ availability from wood ash is based on the level of $P$ in the soil prior to ash application. Decreases in mean foliar $\mathrm{K}$ concentrations could be attributed to $\mathrm{Ca}^{2+}: \mathrm{K}^{+}$soil imbalances from wood ash and pulp/paper residual applications on sandy soils (Guerrini et al. 2000).

\section{Micronutrients}

The Foliar Nutrient Critical Value method identified a single plot with a sub-optimal Zn concentration at both time intervals, but did not provide enough evidence to suggest that wood ash could induce potentially severe $\mathrm{Zn}$ deficiencies in foliage. In addition to time, the main effect of fertilizer type was statistically significant for foliar $\mathrm{Na}, \mathrm{Cu}$ and $\mathrm{Zn}$ concentrations; $\mathrm{F}_{\mathrm{o}}$ treated plots had the greatest concentrations relative to other fertilizer treatments. Nutrients absorbed by Eucalypts often become more diluted as total tree biomass increases over time (Boardman et al. 1997). The decreased macro- and micronutrient concentrations observed at 8 months of age can potentially be explained by the translocation of nutrients in the tree with increasing age, and result in the dilution of nutrient concentrations. In addition, the increased foliar $\mathrm{Mn}, \mathrm{Zn}$ and $\mathrm{B}$ micronutrient concentrations observed at 8 months could likely be a result of the temporary liming effect induced by the wood ash. Cationic micronutrient solubility is strongly governed by soil pH (Bohn et al. 1979) and this may strongly affect foliar nutrient levels. Cationic micronutrients become increasingly available at slightly acidic soil conditions and less available to plants at slightly alkaline conditions (Bohn et al. 1979). The availability of B usually increases when $\mathrm{pH}$ of moderately acid soils are raised.

\section{Heavy metal concentrations}

\section{Soil concentrations}

Cadmium, $\mathrm{Hg}, \mathrm{Cr}$ and $\mathrm{Pb}$ concentrations were well-below the allowable limits set by the National Environmental Management: Waste Act of South Africa. Nonetheless, all soil heavy metal concentrations increased significantly from 4 to 8 months after trial establishment. This could be attributed to the solubility of the heavy metals and soil $\mathrm{pH}$. Patterson (2001) found that the solubility of heavy metals and trace elements like $\mathrm{Cd}$ and $\mathrm{Zn}$ increases as soon as $\mathrm{pH}$ values decrease below 6.5 and considerably more once $\mathrm{pH}$ values decrease from 6 to 5.5. The solubility of heavy metals in wood ash is low and can hinder root uptake (Lévai et al. 2009). The trial site is located close to the industrial town of Richards Bay and the fallout generated by factories on the surrounding areas could likely also affect the 
background soil heavy metal concentrations.

\section{Foliar concentrations}

The increases in $\mathrm{Cd}, \mathrm{Hg}, \mathrm{Cr}$ and $\mathrm{Pb}$ concentrations were significant for the 4 month monitoring period, but the increases were small for the maximum tested wood ash application rate of $1.2 \mathrm{t}$ $\mathrm{ha}^{-1}$. This showed that the tested heavy metals had a low bio-availability and were possibly affected by the edaphic conditions at the trial site (and the greater Richards Bay area). However, the increases were statistically significant and concentrations have to be carefully monitored if heavier wood ash applications are implemented.

\section{Conclusion}

This paper showed that up to $1.2 \mathrm{t} \mathrm{ha}^{-1}$ pure wood ash can safely be disposed of on a typical coastal arenosol with minimal environmental risk from $\mathrm{Cd}, \mathrm{Hg}, \mathrm{Cr}$ and $\mathrm{Pb}$ contamination. Furthermore, wood ash applications of 0.3 to1.2 $\mathrm{t} \mathrm{ha}^{-1}$ on a poorly buffered sandy soil can induce a small temporary liming effect. The changes in soil $\mathrm{pH}$ and heavy metal concentrations showed that the maximum wood ash rate used in this experiment was effectively a conservative rate and a second application or increased application rates are possible. Cadmium, $\mathrm{Hg}, \mathrm{Cr}$ and $\mathrm{Pb}$ concentrations in soil and foliar samples were well-below toxic levels for all application rates; nonetheless the soil levels increased over time and the foliage showed signs of bio-accumulation. This accentuates the importance of intensive soil monitoring if greater wood ash applications are to be implemented. This experiment showed that wood ash applications in combination with a supplementary $\mathrm{N}$ and $\mathrm{P}$ source can (to some extent) substitute nutrients removed from tree harvest operations, without severely affecting stand nutrition and nutrient stability. No ash treatments elicited a significant decrease in stand growth, and ash treatments in combination with NPS fertilizers showed that it can increase growth significantly up to 21 months after treatment implementation. In reference to the hypothesis formulated in the introductory section, we could thus accept part A (because ash application did not affect tree growth) but reject part $B$ (because fertilization did improve growth). The addition of a supplementary $\mathrm{N}$ and $\mathrm{P}$ source is recommended if greater growth increases are expected from wood ash applications to a eucalypt plantation. The effects of wood ash on eucalypt growth and soil properties are site-specific, and it is essential that a comprehensive site-classification, soil analysis and buffer capacity tests are done to prevent the possibility of environmental degradation through over-application or heavy metal contamination.

The importance of this work lies in demonstrating that fertilization combined with wood ash disposal can be safely prac- ticed on coastal plain plantations with low soil buffer capacity, whilst still increasing stand productivity. If implemented, the treatment will reduce pressure on landfill sites and at the same time mitigate against the impact of base cation removals caused by intensive plantation forestry practices over successive rotations.

\section{References}

Aitken RL, Moody PW, McKinley PG (1990). Lime requirement of acidic Queensland soils. I. Relationships between soil properties and $\mathrm{pH}$ buffer capacity. Australian Journal of Soil Research 28: 695-701. - doi: 10.1071/SR9900695

Bird $M$, Talberth J (2008). Waste stream reduction and re-use in the pulp and paper sector. In: Proceedings of the Meeting "Washington State Department of Ecology Industrial Footprint Project". Santa Fe (NM, USA), August 2008. Center for Sustainable Economy, Santa Fe, NM, USA, pp. 1-45.

Boardman R, Cromer RN, Lambert MJ, Webb MJ (1997). Forest plantations. In: "Plant analysis: An interpretation manual ( $2^{\text {nd }}$ edn)" (Reuter DR, Robinson JB eds). CSIRO publishing, Collingwood, Australia, pp. 503-566.

Bohn HL, MCNeal BL, O'Connor GA (1979). Soil Chemistry. Wiley-Interscience, New York, NY, USA, pp. 341.

Dell B, Malajczuk N, Xu D, Grove TS (2001). Nutrient disorders in plantation eucalyptus (2nd edn). ACIAR Monograph 74, Australian Centre for International Agricultural Research, Canberra, Australia, pp. 104.

Demeyer A, Voundi Nkana JC, Verloo MG (2001). Characteristics of wood ash and influence on soil properties and nutrient uptake: an overview. Bioresource Technology 77: 287-295. - doi: 10.1016/S0960-8524(00)00043-2

Donald DGM, Lange PW, Schutz CJ, Morris AR (1987). The application of fertilizers to pines in South Africa. South African Forestry Journal 141: 53-62. - doi: 10.1080/00382167.1987.9630261 Dovey SB, du Toit B, De Clercq WP (2014). Nutrient leaching under zero tension in a subtropical clonal eucalypt plantation on a sandy soil in South Africa. South African Journal of Plant and Soil 31: 153-162. - doi: 10.1080/02571862.20 14.926570

du Toit B, Arbuthnot A, Oscroft D, Job RA (2001). The effects of remedial fertilizer treatments on growth and pulp properties of Eucalyptus grandis stands established on infertile soils of the Zululand Coastal Plain. Southern African Forestry Journal 192: 9-18. - doi: 10.1080/207026 20.2001.10434129

du Toit B, Oscroft D (2003). Growth response of a eucalypt hybrid to fertilization at planting across five site types in Zululand. ICFR Bulletin 21/2003, Institute for Commercial Forestry Research, Pietermaritzburg, South Africa, pp. 30. du Toit B, Dovey SB, Smith CW (2008). Effects of slash and site management treatments on soil properties, nutrition and growth of a Eucalyptus grandis plantation in South Africa. In: Proceedings of the Workshop "Site Management and Productivity in Tropical Plantation Forests" (Nambiar EKS ed). Piracicaba (Brazil) 22-26 Nov 2004 and Bogor (Indonesia) 2-9 Nov 2006. Center for International Forestry Research (CIFOR),
Bogor, Indonesia, pp. 63-78. [online] URL: http://books.google.com/books?id=dımXoGWf $\mathrm{B} 2 \mathrm{CC}$

Elliott A, Mahmood T (2006). Beneficial uses of pulp and paper power boiler ash residues. TAPPI Journal 5 (10): 9-16. [online] URL: http:// cat.inist.fr/?aModele $=$ afficheN $\&$ cpsidt $=183242$ 89

Gavrilescu D (2008). Energy from biomass in pulp and paper mills. Environmental Engineering and Management Journal 7 (5): 537-546. [online] URL: http://citeseerx.ist.psu.edu/view doc/download?doi=10.1.1.466.8038\&rep=rep1\& type $=$ pdf $\#$ page $=47$

Giardina CP, Sanford Jr RL, Dockersmith IC, Jaramillo VJ (2000). The effects of slash burning on ecosystem nutrients during the land preparation phase of shifting cultivation. Plant and Soil 220: 247-260. - doi: 10.1023/A:1004741125 636

Gonçalves JLM, Wichert MCP, Gava JL, Serrano MIP (2008). Soil fertility and growth of Eucalyptus grandis under different residue management practices. In: Proceedings of the Workshop "Site Management and Productivity in Tropical Plantation Forests" (Nambiar EKS ed). Piracicaba (Brazil) 22-26 Nov 2004 and Bogor (Indonesia) 2-9 Nov 2006. Center for International Forestry Research (CIFOR), Bogor, Indonesia, pp. 51-62.

Guerrini IA, Villas Bôas RL, Benedetti V, Comério J, Moro L (2000). Application of wood ash and pulp and paper sludge to Eucalyptus grandis in three Brazilian soils. In: "Principles and Practice of Residual Use". Seattle, College of Forest Resources, University of Washington, pp. 127131. [online] URL: http://www.researchgate. net/publication/242412209

Hans RR (2013). Initial growth responses to controlled release fertilizer application at establishment of commercial forestry species in South Africa. MSc thesis, Department of Forestry and Wood Science, University of Stellenbosch, Stellenbosch, South Africa, pp. 158. [online] URL: http://scholar.sun.ac.za/handle/10019.1/85609 Herselman JE (2007). The concentration of selected trace metals in South African soils. PhD thesis, Department of Soil Science, University of Stellenbosch, South Africa, pp. $58+130$. [online] URL: http://scholar.sun.ac.za/handle/1001 9.1/1390

Jacobson S (2003). Addition of stabilized wood ashes to Swedish coniferous stands on mineral soils - effects on stem growth and needle nutrient concentrations. Silva Fennica 37 (4): 437450. - doi: 10.14214/sf.483

James AK, Thring RW, Helle S, Ghuman HS (2012). Ash management review - application of biomass bottom ash. Energies 5: 3856-3873. doi: $10.3390 /$ en 5103856

Laclau JP, Deleporte P, Ranger J, Bouillet JP, Kazotti G (2003). Nutrient dynamics throughout the rotation of Eucalyptus clonal stands in Congo. Annals of Botany 91 (7): 879-892. - doi: 10.1093/aob/mcgo93

Laidlaw WS, Arndt SK, Huynh TT, Gregory D, Baker AJM (2012). Phytoextraction of heavy metals by willows growing in biosolids under field conditions. Journal of Environmental Quality 41: 134-143. - doi: 10.2134/jeq2011.0241

Lévai L, Veres S, Gajdos E, Marozsán M, Bákonyi 
N, Tóth B (2009). Possibilities in Plant Nutrition. In: Proceedings of the " $44^{\text {th }}$ Croatian and $4^{\text {th }}$ International Symposium on Agriculture". Opatija (Croatia) 16-20 Jan 2009, pp. 556-560. [online] URL: http://sa.agr.hr/pdf/2009/sa2009_po 519.pdf

Mandre M (2006). Influence of wood ash on soil chemical composition and biochemical parameters of young Scots pine. Proceedings of the Estonian Academy of Sciences: Biology, Ecology 55: 91-107.

Mandre M, Korsjukov R, Ots K (2004). Effect of wood ash application on the biomass distribution and physiological state of Norway spruce seedlings on sandy soils. Plant and Soil 265: 301314. - doi: 10.1007/s11104-005-0509-3

Nadel RL, Scholes MC, Byrne MJ (2007). Slash burning, faunal composition, and nutrient dynamics in a Eucalyptus grandis plantation in South Africa. Canadian Journal of Forest Research 37: 226-235. - doi: 10.1139/Xo6-287

Neary DG, Klopatek CC, DeBano LF, Ffolliott PF (1999). Fire effects on belowground sustainability: a review and synthesis. Forest Ecology and Management 122: 51-71. - doi: 10.1016/So3 78-1127(99)00032-8

Ohno T, Erich M (1994). Phosphorus and potas- sium availability in wood ash-amended soils: an incubation study. In: "Maine Sludge Residuals Utilization Research Foundation Research Report no. 2". Department of Plant, Soil and Environmental Sciences, University of Maine, Orono, ME, USA, pp. 1-16. [online] URL: http:// library.wur.nl/WebQuery/clc/156016

Ohno T, Erich MS (1990). Effect of wood ash application on soil $\mathrm{pH}$ and soil test nutrient levels. Agriculture Ecosystem Environment 32: 223-239. - doi: 10.1016/0167-8809(90)90162-7

Patterson S (2001). The agronomic benefit of pulp mill boiler wood ash. MSc thesis, Faculty of Arts and Science, University of Lethbridge, Alberta, Canada, pp. 1-142. [online] URL: http:// hdl.handle.net/10133/127

Pitman RM (2006). Wood ash use in forestry - A review of the environmental impacts. Forestry 79: 563-588. - doi: 10.1093/forestry/cplo41

Romanyà J, Khanna PK, Raison RJ (1994). Effects of slash burning on soil phosphorous fractions and sorption and desorption of phosphorous. Forest Ecology and Management 65: 89-103. doi: 10.1016/0378-1127(94)90161-9

Saarsalmi A, Smolander A, Kukkola M, Moilanen M, Saramäki J (2012). 30-Year effects of wood ash and nitrogen fertilization on soil chemical properties, soil microbial processes and stand growth in a Scots pine stand. Forest Ecology and Management 278: 63-70. - doi: 10.1016/j.for eco.2012.05.006

Scheepers GP (2014). Potential for utilization of wood ash on coastal Zululand soils and its effect on Eucalyptus grandis $\mathrm{x}$ urophylla stand nutrition and growth. MSc thesis, Forestry and Wood Science Department, University of Stellenbosch, South Africa, pp. 143.

Scheepers GP, du Toit B (2016). Potential use of wood ash in South African forestry: a review. Southern Forests [in press]. - doi: 10.2989/207 02620.2016 .1230716

Smith CW, du Toit B (2005). The effect of harvesting operations, slash management and fertilization on the growth of a Eucalyptus clonal hybrid on a sandy soil. Southern African Forestry Journal 203: 15-26. - doi: 10.2989/102959 20509505214

Soares MR, Alleoni LRF (2008). Contribution of soil organic carbon to the ion exchange capacity of tropical soils. Journal of Sustainable Agriculture 32: 439-462. - doi: 10.1080/10440040802 257348 